\title{
De uma "cientificidade difusa": o coronel e as práticas colecionistas do Museu Sertório na São Paulo em fins do século XIX'
}

\section{Paula Carvalho ${ }^{2}$}

RESUMO: Este artigo pretende examinar as práticas colecionistas realizadas em torno do Museu Sertório, uma coleção particular que veio a constituir o primeiro núcleo do acervo do Museu Paulista. Para tanto, serão apresentados alguns dados biográficos inéditos sobre o proprietário do Museu, o coronel Joaquim Sertório, bem como aspectos da organização das coleções, buscando, assim, refletir sobre o suposto amadorismo de Sertório no campo das ciências, uma vez que a abertura do acervo à visitação pública estava associada à intenção de vincular o museu a fins educativos. Procura-se, igualmente, traçar um paralelo entre a trajetória do Museu Sertório com a do Ashmolean Museum of Art and Archaelogy da Universidade de Oxford, Inglaterra, a fim de melhor compreender a sua inserção na São Paulo de fins do século XIX.

PALAVRAS-CHAVE: Museu Sertório. Coronel Joaquim Sertório. Museu Paulista. Colecionismo. Práticas colecionistas.

ABSTRACT: This article intends to examine the collecting practices of the private collection known as Museu Sertório, which became Museu Paulista's first main collection. For that, a brief biography of Colonel Joaquim Sertório, the owner of the Museum, will be presented, as well as aspects of the collections' organization, in order to reflect on Sertório's supposed dilettantism in scientific fields, since the museum was associated with an educational project of the period. A parallel between Museu Sertório and the Ashmolean Museum of Art and Archaelogy, of Oxford University, will also be made, in order to better understand its insertion in nineteenth-century São Paulo.

KEYWORDS: Museu Sertorio. Colonel Joaquim Sertorio. Museu Paulista. Collectionism. Collecting practices.

\begin{abstract}
1. Este artigo é resultado de pesquisa de iniciação científica desenvolvida no Museu Paulista, sob orientação da Prof. ${ }^{a}$ Dr. ${ }^{a}$ Heloisa Maria Silveira Barbuy, com apoio da Fundação de Amparo à Pesquisa do Estado de São Paulo - Fapesp.

2. Historiadora, mestranda em História na EFLCH/ UNIFESP, Guarulhos (SP). E-mail: <paula_carvalho33@ yahoo.com.br>.
\end{abstract}


3. Sobre a formação do Museu Sertório, ver Paula Carolina de Andrade Carvalho (2014, p. 105-152).

4. Ver Fundo Permanente do Arquivo do Estado (1852, n. ${ }^{\circ}$ do lote 2010060003766).

5. Cf. idem.

6. Ver Fundo Permanente do Arquivo do Estado (1870, n. ${ }^{\circ}$ do lote 2010060003766).
Conhecida como Museu Sertório, a coleção particular de propriedade do coronel Joaquim Sertório despontou como o museu de destaque na São Paulo da segunda metade do século XIX. Essa coleção acabou por constituir o primeiro núcleo do acervo do Museu Paulista após ter sido doada para o governo estadual, em 1890, pelo conselheiro Francisco de Paula Mayrink, que havia adquirido as peças de Sertório junto com o prédio que as abrigavam. Em 1895, o Museu Paulista abriu no Monumento do Ipiranga com as coleções Sertório e Pessanha, além de outras aquisições realizadas pelo então diretor Hermann von Ihering para complementar o acervo já existente.

O presente artigo pretende abordar as práticas colecionistas do Museu Sertório e refletir sobre a sua inserção no contexto da São Paulo de fins do século XIX, uma tentativa de melhor compreender o seu papel na cidade. Contudo, para tanto, torna-se necessário mencionar alguns dados pouco conhecidos da biografia de seu proprietário ${ }^{3}$.

Sabe-se que o coronel Joaquim Sertório era um homem rico, nascido na cidade de São Paulo na primeira metade do século XIX. Por meio de inventário e testamento de parentes de Joaquim Sertório - João Sertório, Anna Eufrozina Sertório e Domingos Sertório - foi possível compreender suas relações familiares.

O testamento de João Sertório ${ }^{4}$, falecido em 02 de setembro de 1855, elucidou a história familiar do colecionador. Datado de 25 de maio de 1852, o documento informa que João Sertório é originário de Milão, Itália - tanto que "Sertório" é escrito com a grafia "Sartorio" e o interessado assina "Giovani Sartorio" - filho de "Jacomi Sartorio [sic] e de Antonia Veracci". Ele se declara solteiro e "os que podiam ser meus herdeiros necessários como ascendentes em falta de descendentes legítimos, ou legalmente legítimos, são há muito falecidos". Mesmo assim, João Sertório reconhece ter nove filhos naturais: João Sertório Junior, Domingos Sertório, Henrique Sertório e Galdina Sertório, "havidos por cópula" com Joaquina Justiniana, além de Anna Eufrozina Sertório, Joanna Baptista Sertório, Maria do Carmo Sertório, José Sertório e Joaquim Sertório - o nosso coronel - com Maria Jacintha Gomes ${ }^{5}$.

Ainda declarou que Maria Jacintha Gomes não vivia mais em sua companhia e que, por isso, não tinha qualquer direito a seus bens; ainda anunciou que os seus nove filhos tinham direito a dois terços de seus bens como herança, a saber: sete imóveis e uma chácara "com seus pertences", escravos e dívidas que ainda deveriam ser pagas a ele. A terceira parte da herança seria dividida da seguinte forma: três contos de réis a Joaquina Justiniana Albertim, com quem viveu, "em satisfação dos serviços que me tem prestado", e dois contos de réis às suas quatro filhas, somando, no total, quinhentos mil réis. A mesma quantia caberia a seu afilhado João e o restante seria dividido "irmanamente" entre os seus herdeiros reconhecidos. João Sertório ainda deixou quatrocentos mil réis a Joaquina Justiniana pelos serviços prestados por seu escravo, Pedro de Nação.

O testamento de Anna Eufrozina Sertório ${ }^{6}$ - irmã do coronel que faleceu solteira e sem filhos em 11 de maio de 1870 - nomeia como testamenteiros seus 
irmãos Maria do Carmo Sertório, José Sertório e Joaquim Sertório, deixando para este último a quantia de um conto de réis em dinheiro como "sinal de saudade, lembrança e amizade". Por seus herdeiros universais instituiu os sobrinhos Alberto, filho da sua irmã Maria do Carmo Sertório, e Zulmira, filha da irmã Joanna Sertório Leite com Francisco Custódio Leite. Já o inventário e testamento do Major Domingo Sertório 7 não faz menção alguma ao coronel Joaquim Sertório, seu meio-irmão. Como era solteiro e sem herdeiros diretos, instituiu como herdeiros universais sua irmã, Dona Galdina Sertório, e seu sobrinho, Henrique Sertório ${ }^{8}$.

Essa documentação nos permite traçar as relações familiares do coronel Joaquim Sertório: o italiano João Sertório era seu pai e Maria Jacintha Gomes, sua mãe. Além de quatro irmãos diretos: Anna Eufrozina Sertório, Joanna Baptista Sertório (mais tarde Joanna Baptista Sertório Leite), Maria do Carmo Sertório (mais tarde Maria do Carmo Sertório Raposo) e José Sertório (este se tornaria coronel em Mogi Mirim) tinha quatro meios-irmãos: João Sertório Junior (futuro Barão de Sertório), Domingos Sertório (este se tornaria major), Henrique Sertório e Galdina Sertório, filhos de Joaquina Justiniana Albertim?. Sabe-se igualmente que o coronel foi casado com Maria Ribas Sertório, falecida a 15 de maio de $1901^{10}$, com quem não teve filhos (Figura 1).

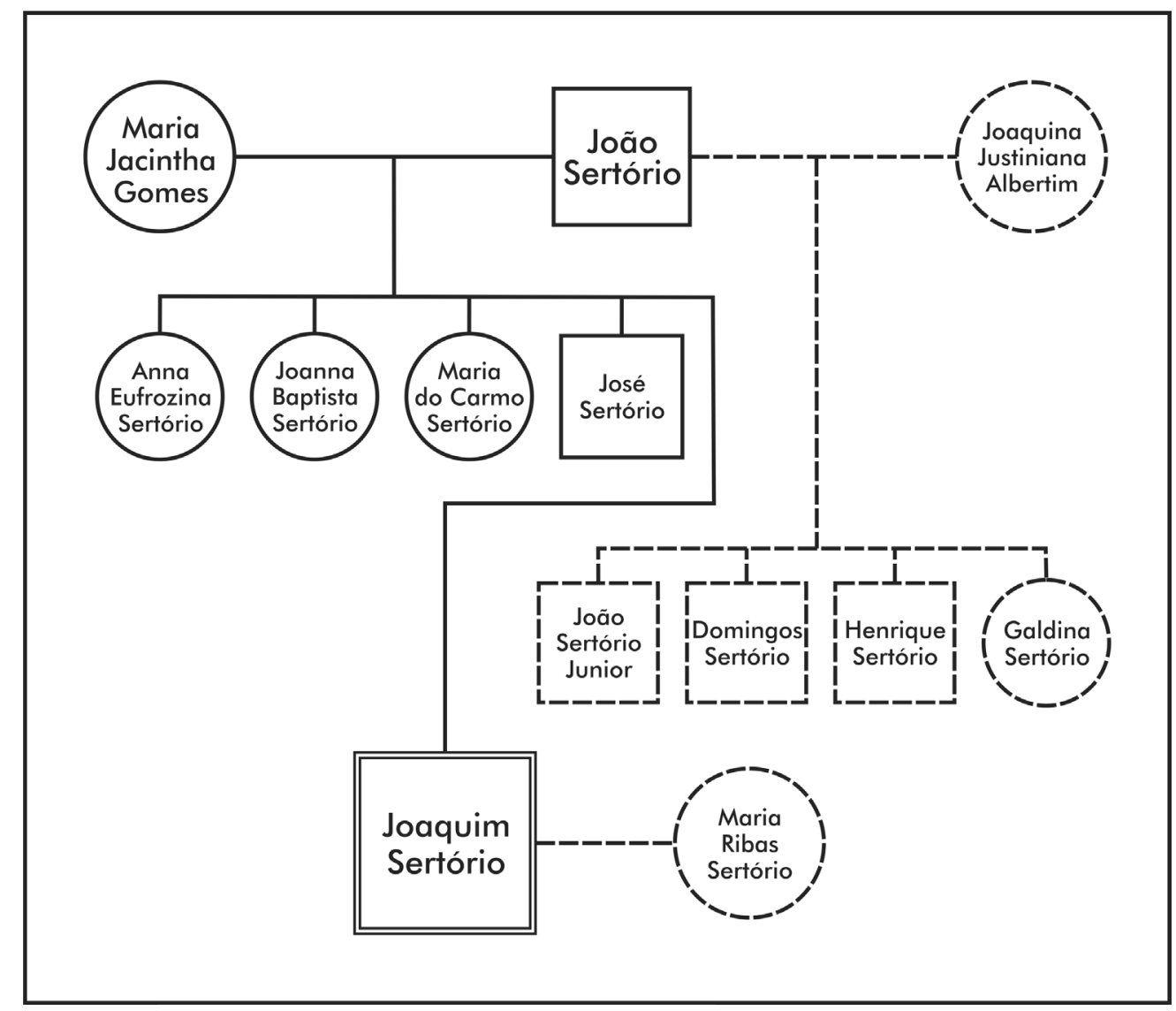

Figura 1 - Heredograma da família de Joaquim Sertório
7. Ver Arquivo do Tribunal de Justiça de São Paulo.

8. Idem.

9. É interessante notar que a imprensa chegou a confundir a origem materna do coronel, como demonstrou a seguinte notícia publicada no Correio Paulistano, 1. ${ }^{\circ}$ dez. 1885, p. 2): "Falecimento - Faleceu ontem nesta capital, às 8 horas da noite, a Exma. Sra. D. Joaquina Justiniana de Albertin [sic], mãe dos Srs. Major Domingos Sertório e Coronel Joaquim Sertório. / Os nossos pêsames à respeitável família da finada."

10. O Estado de S. Paulo (16 maio 1901, p. 2) publicou o seguinte necrológio de Maria Ribas Sertório: "Faleceu ontem, nesta capital, às 6 horas da tarde, a Exma. Sra. D. Maria Ribas Sertório, virtuosa esposa do $\mathrm{Sr}$. Coronel Joaquim Sertório. / A finada, muito estimada pelas suas excelentes qualidades, era irmã dos Srs. Drs. Peixoto Gomide e José Rodrigues Duarte Ribas e da Exma. Sra. D. Leopoldina Ribas, sogra do Sr. Dr. Paulo Egydio. / O enterro realiza-se hoje, saindo o féretro da rua Benjamin Constant, 9, para o cemitério da Consolação. / Não há convites especiais.” A data da sua morte também foi confirmada na inscrição do túmulo da finada, localizado no Cemitério da Consolação, Rua 4, túmulo 8. 
11. Cf. Correio Paulistano (31 jul. 1854).

12. Ver Correio Paulistano (04 de maio de 1855).

13. A Guarda Nacional foi criada pelo governo regencial em 1831 após a abdicação de D. Pedro I, em um momento em que o país entrou em um período de crise política e social. Era uma instituição distinta do Exército, mas que se voltava para a manutenção da ordem e segurança internas. Era formada por civis, entre 18 e 60 anos, com renda mínima para serem eleitores; o alistamento era compulsório e as tropas não recebiam remuneração. Pelo fato de a Guarda Nacional ter tido como base da sua organização o critério de renda, ela acabou por beneficiar as elites locais que adquiriram, portanto, poderes e privilégios. Essa instituição entrou em declínio no final do século XIX, com a proclamação da República, sendo suplantada em importância pelo Exército.

14. Ver Ana Maria de Alencar Alves (2001); Maria José Elias (1996).

15. Ver Correio Paulistano (03 jun. 1856, p. 4).

16. Ver Correio Paulistano (21 nov. 1857; 21 jan. 1858).

17. Ver Correio Paulistano (02 abr. 1857). A Sociedade Carnavalesca era um clube de cunho recreativo que promovia desfiles e bailes de máscaras durante o carnaval, geralmente com caráter competitivo. Era uma forma de as elites se afastarem de manifestações populares que aconteciam nas ruas das cidades.

18. Ver Correio Paulistano (17 nov. 1858); e ofício de Antonio José Barbosa da Veiga, Joaquim Sertório e Caetano Ferreira Balthar ao Presidente da Província Arquivo do Estado de S. Paulo (06 abr. 1858)
Graças a matérias da imprensa foi possível obter algumas informações sobre a trajetória do coronel que ainda permaneciam desconhecidas dos historiadores. As primeiras notícias tratam Joaquim Sertório pela alcunha de "senhor" e um anúncio publicado no Correio Paulistano de 1854 informa estar à venda uma "negra de 38 anos, mais ou menos, sabe lavar, cozinhar, e é muito fiel; não tem vício algum. Quem a pretender dirija-se à casa de Joaquim Sertório, para tratar " 11 . Pode-se assumir que, a exemplo de seu pai, Joaquim Sertório também possuía escravos.

Uma notícia de $1855^{12}$ fala de sua patente, mostrando que Joaquim Sertório, assim como seu meio-irmão, o Major Domingos Sertório, na época era capitão da Guarda Nacional ${ }^{13}$. Confirmando a opinião de certos autores ${ }^{14}$, alguns informes são indicativos de sua atuação como comerciante, caso dos anúncios de classificados que indicam a existência de uma "loja de Joaquim Sertório" situada na ladeira Dr. Falcão latual rua Dr. Falcão Filho, que se encontra com a rua Líbero Badaró na praça do Patriarca ${ }^{15}$ ). Ao ser designado para trabalhar na Freguesia do Brás, Sertório colocou à venda uma chácara de sua propriedade ${ }^{16}$. Nesse meio tempo, também foi diretor da Sociedade Carnavalesca ${ }^{17}$, participou da comissão da Festa da Nossa Senhora da Penha ${ }^{18}$, foi sócio da Sociedade Sete de Setembro ${ }^{19}$ e participou da "Lista dos srs. que tiveram a bondade de contribuir para aliviar a triste sorte das viúvas e órfãos dinamarqueses", tendo colaborado com $10 \$ 000^{20}$. Esses dados mostram que Sertório fazia parte da elite paulista, pois era preciso possuir uma determinada remuneração tanto para integrar a Guarda Nacional quanto para participar da organização de eventos culturais como festas religiosas e carnavalescas.

Em 1868, o Capitão Joaquim Sertório passou a ser tenente-coronel21. Em 1869, Sertório, já na cidade de Limeira, fazia parte da vida política local no partido conservador, sendo um dos escolhidos pelos membros do partido para concorrer às eleições daquele ano, contabilizando 139 votos ${ }^{22}$; posteriormente, foi o sexto mais votado para o cargo de deputado provincial ${ }^{23}$. A sua carreira floresceu: foi nomeado suplente de juiz munícipe e de órfãos ${ }^{24}$; foi o vereador mais votado em Limeira, com 137 votos $^{25}$; em 1873, participou das eleições provinciais ${ }^{26}$; fez parte da comissão de recenseamento de Limeira ${ }^{27}$; e obteve sucesso na eleição provincial de $1875^{28}$.

Naquele município, ele viveu em uma fazenda, onde possuía escravos ${ }^{29}$, passando a inspecionar parte da construção das estradas de ferro da localidade ${ }^{30}$, no que se envolveu em uma polêmica constitucional sobre a legalidade ou não da concessão de um privilégio para a construção de uma estrada de ferro ligando Limeira até as margens do Rio Mojiguaçu ${ }^{31}$. Tornando-se cada vez mais impopular em Limeira, o Coronel Sertório se instalou definitivamente na capital paulista em 1880, onde manteve ativa sua vida política, sendo eleito vereador para o período 1881-1884, tendo ocupado o cargo de vereador por dois anos, 1881 e $1882^{32}$. Na metade de 1882, ele publicou uma declaração afirmando que "não é candidato a vereador da Câmara Municipal na próxima eleição"33. 
No cargo de vereador, Sertório frequentou as sessões da Câmara, participando da Comissão de Obras. É interessante notar sua preocupação com temas ligados a registros históricos, tendo deliberado sobre os arquivos municipais. À comissão encarregada de examinar o relatório apresentado pelo arquivista da Câmara deu o seguinte parecer ${ }^{34}$.

\begin{abstract}
Os arquivos municipais têm um caráter público e a responsabilidade de sua conservação deve pesar sobre o arquivista, de modo que as chaves do local destinado devem estar somente sob a guarda deste funcionário. A escolha do local é essencial, atendendo-se que deve ser abrigado de toda a umidade, que deve ser fácil para a limpeza, e deve estar longe de mãos estranhas. Em tais condições, neste edifício, somente existe uma sala no pavimento superior. É necessária a encadernação dos livros antigos a fim de que o estrago das traças não se desenvolva, assim como a aplicação do sublimado corrosivo para melhor conservação. É necessário que o arquivista redija um inventário ou catálogo dos papéis registrados e livros existentes no arquivo. Seria difícil prescrever um modo uniforme para a redação deste inventário: todavia, o nosso colega da comissão, dr. Americo Braziliense, pessoa competente, deverá dar instruções para esse fim. Notamos que há despesas a fazer para a mudança do arquivo. As estantes estão em bom estado; é necessário adquirir uma mesa para os consultantes a fim de que não haja pretexto algum para transgressão da doutrina do aviso de 22 de julho de 1831. Os próprios vereadores, ainda mesmo sob carga de protocolo, não têm o direito de levar em confiança livros e papéis de arquivo ${ }^{35}$.
\end{abstract}

Essa deliberação mostra que Sertório, por meio da comissão, pediu a realização de um parecer sobre a manutenção dos arquivos municipais, destacando a importância de preservação de documentos da Câmara. Procurou também saber de formas adequadas para essa conservação, como sua instalação em locais apropriados (não úmidos, por exemplo), além de recomendar a encadernação de livros antigos e a aplicação de substâncias químicas para evitar a destruição desses documentos pelas traças. $\bigcirc$ relatório também destaca a necessidade de um inventário ou catálogo da documentação existente a fim de auxiliar na organização do arquivo, além da compra de uma mesa que deveria ser usada pelos visitantes. O que é mais interessante, entretanto, é a declaração do caráter público desse arquivo, sendo aberto a consultas, e o aviso de que os vereadores não poderiam usufruir a documentação do arquivo de forma particular, pois esta pertenceria à esfera pública sob a qual a própria Câmara deveria resguardar.

Além disso, Sertório indicou que a Câmara pedisse ao Governo Provincial a cópia de um documento de Martim Afonso de Sousa ${ }^{36}$, e remetesse ao Governo Provincial documentos relativos à antiga Casa da Pólvora ${ }^{37}$. Também requereu ao Governo Provincial o envio de documentos antigos à Câmara ${ }^{38}$. $O$ coronel também fez parte de um grupo de vereadores que propôs a criação de uma Escola de Farmácia e de um curso superior de Ciências Naturais ${ }^{39}$. Essas ações demonstram preocupação com o ensino e o desenvolvimento das ciências naturais na cidade, assim como com a preservação da memória local por meio da conservação de documentos importantes para a história de São Paulo.

Após deixar a política, Sertório parece dedicar-se quase integralmente ao seu Museu, ganhando dinheiro por meio de transações imobiliárias ${ }^{40}$ e da
19. Ver Correio Paulistano (09 ago. 1854; 12 jan. 1859). A Sociedade Sete de Setembro era "uma sociedade de beneficência particular que tinha por objetivo educar meninas órfãs, a fim de prepará-las para o magistério ou o casamento". Cf. Correio Paulistano (30 mar. 1855).

20. Cf. Correio Paulistano (03 jul. 1864, p. 2). A questão das viúvas e órfãos dinamarqueses referia-se à situação desse grupo devido à "invasão dinamarquesa a ducados da Alemanha". Cf. Correio Paulistano (14 jun. 1864, p. 3).

21. Ver Correio Paulistano (23 set. 1868).

22. Ver Correio Paulistano (29 fev. 1869).

23. Ver Correio Paulistano (10 set. 1869).

24. Ver Correio Paulistano (13 jul. 1872).

25. Ver Correio Paulistano (13 set. 1872).

26. Ver Correio Paulistano (22 out. 1873; 24 out. 1873; 30 out. 1873).

27. Ver Correio Paulistano (28 dez. 1873).

28. Ver Correio Paulistano (24 out. 1875). Aparentemente, Sertório participou da Comissão de Instrução Pública da Assembleia Provincial ao menos em 1877 , pelo que se depreende de uma carta enviada à Provincia de $S$ Paulo (10 fev. 1877, p. 2), que ironizava o estado de conservação da instituição; a comissão seria formada por "Coronel Sertório, vigário Bicudo, dr. Luiz Silverio" (grifo nosso).

29. Ver Correio Paulistano (16 set. 1869 , p. 3).

30. Ver Correio Paulistano 
(05 fev. 1869; 16 maio 1872).

31. Ver Correio Paulistano (14 maio 1874; 11 mar. 1875); A Provincia de $S$. Paulo (14 abr. 1877).

32. Para aprofundar-se na atuação política de Sertório na capital, ver: $A$ Provincia de S. Paulo (02 jul. 1880, p. 2; 04 jul. 1880 , p. 2 ; 06 jul. 1880 , p. $2 ; 18$ jan. 1881, p. 2; 01 fev. 1881, p. 3; 04 fev. 1881 , p. $1 ; 21$ set. 1881 , p. $2 ; 16$ nov. 1881 , p. $2 ; 1 .^{\circ} \mathrm{dez}$. $1881 ; 05$ jan. 1882 , p. $2 ; 14$ jan. 1882, p. 1; 21 fev. 1882, p. $1 ; 29$ mar. 1882 , p. $1 ; 30$ mar. 1882 , p. $1 ; 18$ abr. 1882 ; 16 maio 1882 , p. $2 ; 02$ jul. 1882 , p. 2; 10 out. 1882 , p. 2); Correio Paulistano (23 jun. 1880 , p. 2 ; 04 jul. 1880 , p. $2 ; 06$ jul. 1880 , p. $2 ; 21$ jul. 1880 , p. 2 ; 03 ago. 1880 , p. 3; 04 ago. 1880, p. 3; 19 jan. 1881, p. 1; 02 fev. 1881, p. 4; 15 fev. 1881 , p. 2 ; 17 fev. 1881 , p. $2 ; 10$ mar. 1881 , p. 2; 16 mar. 1881 , p. 2 ; 22 mar. 1881, p. 2; 29 mar. 1881 , p. 2; 08 abri. 1881, p. 2; 22 abr. 1881, p.1-2; 28 abr. 1881, p. 2; 05 maio 1881 , p. $1 ; 10$ maio 1881 , p. 2; 20 maio 1881 , p. $2 ; 12$ jul. 1881 , p. 2 ; 21 set. 1881 , p. 2; 07 jul. 1881, p. 2; 30 jul. 1881 , p. $2 ; 06$ ago. 1881 , p. 2; 15 ago. 1881 , p. $1 ; 18$ ago. 1881 , p. 2 ; 08 set. 1881 , p. $1 ; 21$ set. 1881 , p. $1 ; 1 .^{\circ}$ out. 1881 , p. 3; 05 out. 1881, p. 1; 07 out. 1881 , p. 1 ; 11 out. 1881 , p. 2 ; 14 out. 1881 , p. 2 ; 21 out. 1881, p. 1 ; 27 out. 1881 , p. 2 ; 09 nov. 1881 , p. 1; 15 nov. 1881 , p. 1 ; 17 nov. 1881 , p. 1 ; 08 dez. 1881 , p.12; 13 dez. 1881, p. $1 ; 17$ dez. 1881, p. 1; 21 dez. 1881, p. 1; 27 dez. 1881 , p. $2 ; 17$ jan. 1882 , p. 2 ; 24 jan. 1882 , p. 2; 31 jan. 1882 , p. 2; 13 fev. 1882 , p. $2 ; 17$ jan. 1882 , p. 2; 25 fev. 1882 , p. $2 ; 22$ mar. 1882 , p. $1 ; 28$ mar. 1882 , p. 1 ; 02 maio 1882 , p. 2; 09 maio 1882, p. 2 ; 22 jun. 1882 , p. 1 ; 06 out. 1882 , p. 1; 18 jan. 1883, p. 3; 24 jan. 1883 , p. 2 ; 02 maio 1883 , p. 1). formação de uma casa de comissões de café e outros gêneros em sociedade com a firma Valencio Leomil \& C. e dr. Francisco de Assis Peixoto Gomide ${ }^{41}$.

A data de falecimento do Coronel Sertório é 05 de dezembro de 1905. Essa informação foi primeiro encontrada nos jornais da época, que publicaram necrológios quando da sua morte ${ }^{42}$. Essa data é confirmada na Certidão de Óbito de Joaquim Sertório, assim como outras informações trazidas pelas notícias: era viúvo; tinha 78 anos de idade; residia na Rua Benjamin Constant, n. 9, em São Paulo; faleceu às 5 horas da manhã, em casa. A Certidão ainda registra que a causa da morte foi broncopneumonia. $\bigcirc$ sepultamento ocorreu no Cemitério da Consolação; sendo declarante José Sertório do Valle, e o médico que atestou o óbito Dr. A. Fajardo; e como observações finais: "Deixa testamento. Era viúvo de Maria Ribas Sertório. Não deixa filhos. Nada mais"43.

\section{Museu Sertório}

Com esses dados, vê-se que o Coronel Joaquim Sertório era uma figura proeminente na sociedade paulista, mantendo vínculos com homens importantes do período. Inicialmente, fez carreira na Guarda Nacional, para depois se lançar na vida política. Homem rico e de posses - sendo proprietário, inclusive, de muitos imóveis -, comerciante, Sertório tinha os meios materiais para acumular uma coleção de objetos. Mas o que se deve destacar, a partir da sua trajetória política, é o seu interesse em relação às ciências e à educação, diante da sua participação na Comissão de Instrução Pública da Assembleia Provincial, em 1877; da sua proposta de criar-se uma Escola de Farmácia e um curso superior de Ciências Naturais, em São Paulo; do seu conhecimento sobre organização de arquivos, além de atentar para o destino de documentos antigos ligados à história da cidade. A sua ligação com a questão da instrução e da história mostra que, ao contrário do que a historiografia infere ${ }^{44}$, Sertório possuía algum conhecimento científico, além de demonstrar preocupação com os vestígios materiais da história da província. Mesmo assim, a origem desse conhecimento, ou desse interesse científico, permanece nebulosa, pois ainda não se sabe como se deu a educação de Sertório, e isso ajudaria a compreender a organização da sua coleção ${ }^{45}$.

Após esta breve biografia de Joaquim Sertório, é pertinente aprofundar o debate sobre o suposto amadorismo do coronel no campo das ciências e do colecionismo. Segundo Elias, ele foi retratado como uma "pessoa abastada e solitária, possuidora de uma paixão pelo colecionismo", não sendo, portanto, um cientista, nem um estudioso; a seu ver, sua "paixão pelas coleções" não era nada mais que um "custoso passatempo de homem rico"46. $\bigcirc$ jornalista Ezequiel Freire afirmou que o coronel não era um naturalista, mas apenas um colecionador, sendo que suas coleções estavam dispostas "(...) mais em atenção ao efeito que pudessem produzir os agrupamentos do que em vista das classificações científicas", sendo que na mesma vitrina podiam "casualmente encontrar-se reunidos indivíduos dos mais disparatados feitios e índole: uma tartaruga ao lado de um beija-flor, de um 
cristal de quartzo, ou de uma espada histórica"47. A mesma impressão teve Alberto Loefgren quando visitou o Museu Sertório ${ }^{48}$.

Ana Maria Alencar Alves observou que os relatos de Ezequiel Freire sobre o Museu Sertório, expressando seu desagrado com a mistura de objetos, mostrava

(...) o desejo de acompanhar as concepções científicas do final do século XIX, que tendiam para a especialização, rejeitando a mistura, antes, comum. O mesmo bric-à-brac - como diziam os eruditos da época versados no francês -, a mesma barafunda existia quando da criação do Museu Nacional, em 1818, ou do Museu Paraense, em 1866. As críticas de Freire, feitas na década de 1880, anunciavam mudanças que iriam definir melhor as fronteiras entre a História Natural e a História, entre as disciplinas e espaços institucionais ${ }^{49}$.

Essa aparente falta de sistematização científica da coleção foi sublinhada nos relatos de visitantes. Segundo o cronista alemão Carl von Koseritz, que visitou - Museu em 1883, o coronel, destituído de preocupação científica, "(...) encheu completamente a sua casa de uma quantidade de objetos dos mais diferentes gêneros. Há ali muita coisa inútil ao lado de material extraordinariamente importante"50. A falta de classificação científica, "não só de objetos, como na colocação das coleções", também foi observada por um jornalista que acompanhou a visita de D. Pedro II ao Museu, em 188651. O médico italiano Alfredo Lomonaco afirmou, após visitar o Museu em 1886, que "todas as coleções estão abarrotadas e acumuladas umas ao lado das outras, o que, ao longo da visita, diminui o valor das peças" 52 . Em 1890, o cronista Henrique Raffard comentou que "infelizmente ainda não há catálogo nem rótulo em todos os objetos para que se possa avaliá-los devidamente"53. Para Elias, "Sertório levou esse colecionismo muito longe; sua residência ficou atulhada por toda a sorte de objetos" 54 .

Porém, é importante ressaltar que uma coleção geralmente possui uma determinada organização - com relação à de Sertório, não se sabe ainda como ele a classificava ou que lógica the imprimia. Para Peter Burke, a organização das coleções é um dos aspectos mais interessantes do colecionismo, pois os estudiosos tentam descobrir a lógica dos mais variados sistemas de classificação ${ }^{55}$. Portanto, é provável que Sertório tenha criado uma sistematização própria. Uma observação feita por Loefgren em 1881 pode lançar alguma pista sobre a questão: "Estas coleções, é verdade, ainda não estão classificadas, antes são arranjadas mais segundo a estética do que conforme as classificações científicas" 56 . Com isso, é possível que Joaquim Sertório tenha arrumado suas coleções segundo os critérios da sua sensibilidade visual, seguindo nesse aspecto o modelo dos gabinetes ${ }^{57}$. Como atestou Giuseppe Olmi, em relação aos gabinetes de curiosidades na Itália dos séculos XVI e XVII, muitos deles estavam organizados de forma calculada a "agradar os sentidos do visitante" 58 . Ao mesmo tempo, segundo Antoine Schnapper, o gabinete - que tomou esse nome em vista do móvel que encerra objetos em gavetas - tinha na miscelânea a sua essência, uma vez que, "na gaveta do mesmo gabinete, podem ser encontradas pedras gravadas e conchas, medalhas e corais" 59 .
33. Cf. A Provincia de $S$. Paulo (22 jun. 1882, p. 1).

\begin{abstract}
34. Nas citações de notícias de jornal, procurou-se seguir a formatação dos jornais da época, dando destaque a títulos ou subtítulos, além de mostrar palavras em itálico quando o próprio jornal as formatava dessa forma. A grafia da época foi atualizada para os padrões atuais.
\end{abstract}

35. Cf. A Provincia de $S$. Paulo (22 jun. 1882, p. 225226). Essa organização dos arquivos locais seguia o mesmo movimento internacional de formação dos Arquivos Nacionais na Europa: "Na França, a revolução cria os Arquivos Nacionais e a 25 de julho de 1874 declara seu caráter público. Em outros países, o exemplo se repete. Em Turim, São Petersburgo, Veneza, Florença, na mesma época, depósitos centrais de arquivos são criados". Cf. Lilia Moritz Schwarcz (2007, p. 67).

36. Ver Atas da Câmara (1882, p. 35).

37. Ibid. loc.cit.

38. Ibid. (p. 65).

39. Ibid. (p. 189).

40. Para informações sobre registros de vendas imobiliárias e quitações de hipoteca ver Correio Paulistano (10 fev. 1888, p. 2; 14 fev. 1903, p. 2; 21 mar. 1903 , p. 3; 20 maio 1903, p. 3 ; 02 out. 1903 , p. 1 ); $1^{\circ}$ Cartório de Notas da Capital - Livro de Outorgas (n. 101, pp. 8-9); $2^{\circ}$ Cartório de Notas da Capital - Livro de Outorgas $\left(\mathrm{n}^{\circ} 82\right)$.

41. Ver A Provincia de $S$. Paulo (19 set. 1884). É interessante destacar que Peixoto Gomide era cunhado de Sertório, pois era casado com Maria Ribas Sertório, irmã de Gomide. 
42. Ver A Provincia de $S$. Paulo (06 dez. 1905, p. 3).

43. No Cartório Sul da Sé, em São Paulo, extraiu-se uma via dessa certidão. Cf. Certidão de Óbito $\left(\mathrm{N}^{\circ}\right.$ de matrícula: 1228040155 19054000190500000541 88, Livro C-0019, Folha 050F, Termo 541).

44. Maria José Elias (1996, p. 138) descreve Joaquim Sertório como "um rico comerciante estabelecido na cidade de São Paulo, na segunda metade do século XIX. Registros da época retratam-no como uma pessoa abastada e solitária, possuidora de uma paixão pelo colecionismo. Não era, pois, um cientista e - tudo indica - nem mesmo um estudioso. Não se conhece nenhum trabalho técnico ou científico de sua autoria. Sua 'paixão pelas coleções' parece-nos somente um custoso passatempo de homem rico". Para Ana Maria de Alencar Alves (2001, p. 51), as coleções do Museu Sertório "já funcionavam informalmente como um museu (...) Seguindo um costume da época, as coleções abarrotavam a casa de Sertório - um 'curioso', como os cientistas costumavam referir-se aos colecionadores que não eram cientistas que as franqueava a visitas". Essas duas passagens transmitem a ideia de que as coleções de Joaquim Sertório eram uma espécie de capricho de homem rico, tornando-se um museu "informal" na cidade. É bem provável que os primórdios do Museu Sertório tenham tido esse caráter, mas a partir da trajetória desse estabelecimento, conforme. Paula Carolina de Andrade Carvalho (2014), é possível perceber que o coronel procurou desenvolver suas coleções com bases científicas visando à educação, conforme será abordado mais adiante neste artigo.
Mesmo assim, Sertório contratou Loefgren para organizar suas coleções conforme os preceitos científicos da época. Não se sabe se Loefgren foi chamado por Sertório ou se o cientista ofereceu-se para cuidar das suas peças; também é ainda incerta a data do início dos seus trabalhos com o Museu Sertório, mas é possível afirmar que em 1883 ele já estava envolvido com essas coleções, como informou Koseritz ${ }^{60}$.

que se sabe também é que Loefgren conhecia o Museu desde 1881 , em virtude de um artigo publicado na imprensa assinado por ele discorrendo sobre a coleção ${ }^{61}$. Em 1882, os dois já mantinham contato profissional, como indicou um anúncio em que o cientista oferecia seus trabalhos como professor, e Sertório era um dos responsáveis por fornecer informações sobre o botânico no Colégio Morton, localizado na Rua da Consolação ${ }^{62}$. Após esse contato inicial, Loefgren chegou a acompanhar o coronel em algumas expedições ${ }^{63}$.

Ao mesmo tempo que existiu um discurso que apontava para a falta de critério científico por parte de Joaquim Sertório, havia uma outra visão sobre a sua pessoa que, além de servir de contraponto, mostrava que ele tinha uma certa preocupação com o conhecimento, sugerindo que não era apenas um diletante:

Não há morador ou visitante desta cidade interessado em observar espécimes das riquezas minerais do nosso solo, das coleções da flora e fauna brasileiras e bem assim de objetos destinados aos estudos de história e etnografia pátria que não conheça e admire o valioso museu organizado pelo nosso ilustre amigo Sr. Coronel Joaquim Sertório. Constante e infatigável nas suas pesquisas, tem o proprietário desse museu reunido exemplares raros e curiosíssimos relativos às ciências, belas-artes, letras e indústrias, quer dos mais remotos períodos da fundação do Brasil, e sobretudo da Província de S. Paulo, quer de épocas recentes ${ }^{64}$.

Sertório realizava expedições, algumas inéditas segundo a imprensa, aparentemente com fins de produção de conhecimento, como a sua ida a São Vicente para examinar sambaquis; estava previsto também que os resultados desses estudos seriam publicados a fim de esclarecer se São Paulo era um dos locais de reprodução das "duas raças diferentes que habitaram o Brasil" durante o período pré-histórico65.

É provável que Sertório não tenha publicado artigo científico algum com relação a essas descobertas, caso algum estudo tenha sido realmente realizado. Mesmo assim, é importante destacar a intenção de produzir conhecimento científico e difundi-lo. Ainda de acordo com essa ideia, é interessante deparar-se com a notícia de que o colecionador planejava montar um gabinete físico e um laboratório químico para "preleções públicas e populares"66 lo que não chegou a se concretizar), além de manter o Museu.

Sertório também teria exibido no Museu um indígena vivo, de algum modo seguindo o formato da Exposição Antropológica de 1882, ocorrida no Museu Nacional, no Rio, que expôs uma família de índios Botocudo vinda do Espírito Santo e três Xerente, além de várias coleções geológicas, botânicas e 
zoológicas trazidas do Museu Paraense Emílio Goeldi67, e de vários artefatos arqueológicos e antropológicos que o próprio diretor do museu na época, Ladislau Neto, coletou em aldeias indígenas. Essa exposição foi inaugurada em 29 de jutho de 1882 e durou três meses. Foi considerada um enorme sucesso, contando com mais de mil visitantes (cifra alta para a época), e obteve repercussão internacional. Segundo Lopes, ela foi "considerada a primeira em seu gênero em todo o mundo pela imprensa e autoridades locais, (...) atestando o vigor e o impulso que esse campo de conhecimento vinha recebendo (...)"68. Essa ocorrência mostra como o coronel estava a par das práticas expositivas adotadas na época.

O caso do índio exposto no Museu Sertório foi envolto por polêmica. O índio Apyla, um garoto Xavante de nove anos, foi trazido em 1886 a São Paulo pelo naturalista viajante J. P. da Motta Junior ${ }^{69}$ - contratado do Museu Sertório - como "nova colheita" para o Museu Sertório. Filho do cacique Anxo e da índia Faim, ele foi capturado quando os pais foram assassinados no lugar denominado Pontinhas, distrito de S. José dos Campos Novos, em 188370. A polêmica iniciou-se em Campinas, quando o dr. Balthazar da Silva Carneiro denunciou ao Imperador, aos Governos Geral e Provincial e à Câmara dos Deputados o fato de que Apyla teria sido exposto no Museu Sertório71; denúncia semelhante foi feita pelo senador Martinho Campos ${ }^{72}$. O Correio de Campinas informou que Apyla andaria pelo Museu Sertório vestido de soldado, como "um ornamento, uma curiosidade", ao passo que o crânio do seu pai, o cacique Anxo, também estaria em exibição no local. Essa denúncia foi desmentida pelo Correio Paulistano, que afirmou ter enviado uma pessoa ao Museu a fim de verificar a veracidade da informação, concluindo ser destituída de fundamento, e elogiando a "nobreza d'alma" do coronel por ter sob sua proteção uma "indiazita Guarani", que estudava no colégio de meninas de ltu³. Segundo Motta Junior, Apyla não andava fardado, "mas sim decentemente vestido", nunca esteve exposto à "curiosidade pública", e não se encontrava na capital, mas em Santos ${ }^{74}$.

De alguma forma, essas ações de Sertório podem ser entendidas no contexto brasileiro da época que, na visão de Schwarcz, não tanto valorizava o avanço científico sob forma de pesquisas originais, mas sim de uma "cientificidade difusa' e indiscriminada", o que significa que a ciência penetrou primeiro como "moda" para depois ser reconhecida na sua prática e na sua produção ${ }^{75}$. Sertório pode ter se embrenhado nesse caminho científico seguindo essa "moda", uma vez que não há registros de que tenha produzido algum trabalho científico.

Frente a essas informações, o presente estudo tende a favorecer a visão de Sertório como um homem que, mesmo não tendo sido instruído formalmente nas ciências, desenvolveu uma preocupação científica à medida que aumentava as coleções do seu Museu. É preciso, primeiro, lançar uma hipótese sobre os motivos iniciais para seu colecionismo, que posteriormente foi organizado em um museu, com vistas aos padrões classificatórios do final do século XIX.
É interessante notar que alguns relatos de contemporâneos ao Museu Sertório também destacam o lado "curioso" do coronel. A saber, Carl von Koseritz (1980 [1883]); Ezequiel Freire, no Correio Paulistano (27 set. 1882); o cientista Orville Derby comenta em correspondência o aspecto "curioso" das coleções de Sertório, in Maria Margaret Lopes \& Silvia Fernanda de Mendonça Figueirôa (2003)

45. É possível que o interesse científico de Sertório tenha surgido ou sido melhor formulado após ter travado contato com o botânico sueco Alberto Loefgren, que foi indicado em 1891 como diretor interino do Museu do Estado após a doação da coleção ao governo estadual

46. Cf. Maria José Elias (1996, p. 138).

47. Cf. Correio Paulistano (27 set. 1882 , p. 2 ).

48. Ver Correio Paulistano (19 nov. 1881, p. 1).

49. Cf. Ana Maria de Alencar Alves, 2001, pp. 133-134.

50. Cf. Carl von Koseritz (1980 [1883], p. 267).

51. Cf. Correio Paulistano (19 nov. 1886, p. 2).

52. Cf. Alfonso Lomonaco (1889, p.122).

53. Cf. Henrique Raffard (1977 [1890], p. 87).

54. Cf. Maria José Elias (1996, p. 138).

55. Ver Peter Burke (2005).

56. Cf. Correio Paulistano (19 nov. 1881, p. 1).

57. Para outras similaridades entre o Museu Sertório e os gabinetes de curiosidades da Europa moderna, ver Paula Carolina de Andrade Carvalho (2014). 
58. Cf. Giuseppe Olmi (1985, p. 8-9).

59. Cf. Antoine Schnapper (1988, p. 11).

60. Ver Carl von Koseritz (1980 [1883]).

61. Ver Correio Paulistano (19 nov. 1881)

62. Ver A Provincia de $S$. Paulo (27 jun. 1882, p. 3).

63. Ver A Provincia de $S$. Paulo (29 ago. 1884, p. 2).

64. Cf. Correio Paulistano (27 set. 1884, p. 1).

65. Cf. A Provincia de $S$. Paulo (08 jul. 1884, p. 1).

66. Cf. A Provincia de $S$. Paulo (10 jun. 1884, p. 1).

67. Sobre a formação do Museu Paraense Emílio Goeldi, ver Nelson Sanjad (2005).

68. Cf. Maria Margaret Lopes (1997, p. 176-177).

69. Pouco se sabe sobre como J. P. da Motta Junior entrou em contato com o Coronel Sertório, e como foi contratado para ser naturalista viajante do Museu. O que se sabe é que J. P. da Motta Junior era redator do Rio Branco de Pirassununga, sendo ele também um colecionador.

70. Ver Correio Paulistano (26 ago. 1886, p. 2).

71. Ver Correio Paulistano (07 set. 1886, p. 2).

72. Ver Correio Paulistano (31 ago. 1886, p. 2).

73. Cf. Correio Paulistano (11 set. 1886 , p. 2 ).

74. Cf. Correio Paulistano (11 set. 1886 , p. 2 )

75. Cf. Lilia Moritz Schwarcz (2007).

\section{colecionismo de Sertório}

É possível que Joaquim Sertório, diante de sua trajetória, tenha se voltado para a prática colecionista, primeiro, como um passatempo digno de um homem rico, ainda não preocupado com as ciências. Como escreveu Pomian, o fato de possuir certas peças

confere prestígio, enquanto testemunham o gosto de quem as adquiriu, ou as suas profundas curiosidades intelectuais, ou ainda a sua riqueza ou generosidade, ou todas estas qualidades conjuntamente. Não é caso para espanto, então, que se encontrem pessoas que queiram apropriar-se de tais objectos e que para atingirem este fim sacrifiquem uma parte das suas fortunas; ou outras que, não podendo apropriar-se de tais objectos, queiram ter pelo menos o direito de olhá-los 76 .

Ao estudar os gabinetes italianos dos séculos XVI e XVII, Giuseppe Olmi observou que colecionar objetos era mais uma forma de passar o tempo do que uma atividade científica, algo que oferecia prestígio e renome, e que auxiliava na ascensão social, uma vez que permitia ao colecionador oportunidades de atrair personalidades de sangue real para a sua casa e de guiá-los pelo seu museu.

Museu Sertório, de alguma forma, passou por processo semelhante, tornando-se um lugar digno de ser visto em São Paulo, inclusive recebendo visitas do imperador D. Pedro II. Portanto, a coleção, para o coronel, pode ter se tornado uma atividade com fins de obter certo prestígio social pelo reconhecimento de ser um homem preocupado com a instrução.

Segundo Pomian, há uma hierarquia de valor entre os detentores de objetos de coleções - que o autor chama de "semióforos"77 - uma vez que

o poder domina o saber; o saber sagrado luta para manter a sua proeminência e o seu domínio sobre o saber profano; no interior deste último, ocupações diferentes não têm o mesmo estatuto. Quanto à riqueza, exactamente porque consiste apenas na posse dos instrumentos de constrição económica sob a forma de dinheiro ou de meios de produção, é posta no fundo da escala. Mais uma vez se constata que o significado é superior à utilidade ${ }^{78}$.

Assim, compreende-se a aquisição de semióforos para a formação de coleções como

uma das operações que, ao transformar a utilidade em significado, permitem a quem tenha uma alta posição na hierarquia da riqueza ocupar uma posição correspondente na do gosto ou do saber, sendo as peças de colecção, como se viu, símbolos de pertença social, senão de superioridade. A aquisição de semióforos equivale portanto à do bilhete de entrada num meio fechado e ao qual não se pode aceder sem ter retirado uma parte do dinheiro que se possui do circuito utilitário79.

Paula Findlen, ao escrever sobre os gabinetes italianos nos séculos XVII e XVIII, período em que o colecionismo floresceu na Europa moderna, a prática de colecionar era uma atividade da elite social educada: "Ao possuir objetos, uma 
pessoa conseguia adquirir conhecimento, e por meio da sua exibição, iria adquirir de forma simbólica a honra e a reputação cultivadas por todos os homens instruídos." ${ }^{80}$. Esse raciocínio pode também ser aplicado a Joaquim Sertório, uma vez que constituir uma coleção particular era uma forma de mostrar-se preocupado com o cultivo do conhecimento, ainda mais em uma cidade carente desse tipo de instituição e que buscava - por meio dos discursos de suas elites -inserir-se no processo civilizatório europeu.

Esse interesse pelas ciências também acompanha o contexto brasileiro da segunda metade do século XIX, marcado por um "surto de desenvolvimento material (...) que incorporou a valorização da ciência como prática concreta e como instituição social na remodelação da face do país"81. A criação de museus como o Museu Paraense Emílio Goeldi, em 1871, foi um dos reflexos desse "despertar"82, consolidado por ações de diferentes elites locais e de iniciativas científicas regionais que seguiam a renovação do "movimento internacional de museus", diante da "expansão das diferentes áreas disciplinares e instituições científicas e pelo incremento da especialização e profissionalização dos técnicos e cientistas" ${ }^{\prime 83}$. Esse período também foi marcado por uma nova forma de se compreender o Brasil, a partir do fim da Guerra do Paraguai, em 1870, quando começam a ser questionados o sistema monárquico e escravista em prol da manutenção do sistema agrário.

Segundo Lopes, foi esse o momento em que a hegemonia econômica das elites do café do Rio de Janeiro começou a ser ameaçada pela ascensão dos fazendeiros paulistas, ao passo que a cultura da cana-de-açúcar já havia entrado em decadência no Nordeste e a exportação de borracha introduzia a Amazônia no âmbito internacional. $\bigcirc$ desafio de modernizar o país, que procurou conciliar os interesses das novas elites cafeicultoras com a manutenção do poder monárquico, gerou várias contradições que buscaram ser sanadas pelo governo com a importação de mão-de-obra imigrante para as lavouras - também realizada para - "branqueamento da raça" com o intuito de introduzir o Brasil entre o grupo das nações europeias vistas como "civilizadas" -, com o desenvolvimento de redes de comunicação e meios de transporte, investimento em comissões técnicas (para definir fronteiras e reunir conhecimentos geográficos e geológicos sobre o país), e com a implantação de medidas de urbanização e higienização. As ciências foram as bases ideológicas para a implementação desse processo de modernização conservadora ${ }^{84}$.

Isso fica claro quando se percebe que o cientificismo no país foi caracterizado não só pela valorização das ciências, mas também por

\footnotetext{
estender os métodos das ciências naturais ao estudo dos fenômenos humanos e sociais [...]. Assumiu-se nas análises da sociedade brasileira a essência classificatória das ciências naturais, e portanto dos museus, popularizada pelas formas específicas das classificações hierárquicas, das teorias da evolução social, que correlacionavam a evolução das sociedades à biologia, substituindo os organismos vivos pelos grupos humanos ${ }^{85}$.
}

76. Krzysztof Pomian (1984, p. 54).

77. "Semióforos" seriam todos os objetos que não têm utilidade prática, mas que representam o invisível e, por isso, seriam dotados de significado e fariam parte de coleções, contrapondo-se aos objetos que têm um valor de uso proeminentes, ajudando o homem a transformar a natureza.

78. Cf. Krzysztof Pomian (1984, p. 79).

79. Cf. Ibidem.

80. Cf. Paula Findlen (1994, p. 2).

81. Cf. Maria Margaret Lopes (1997, p. 153).

82. O cientista norteamericano Orville Derby, que trabalhou no Museu Nacional e foi diretor da Comissão Geográfica e Geológica de São Paulo, em artigo publicado em 1883 na revista Science, afirmou que houve um "despertar" no Brasil para a importância da pesquisa científica na década de 1870 . Para Maria Margaret Lopes (1997, p. 154), esse movimento não surgiu do nada, mas veio de uma necessidade de "adequar aspectos institucionais e concepções científicas que à época se transformavam radicalmente, particularmente no âmbito das Ciências Naturais. Na verdade, todo um conjunto de atividades científicas já vinha expandindo-se, alterando seus paradigmas e se consolidando".

83. Cf. Maria Margaret Lopes (1997, p. 153).

84. Ibidem.

85. Cf. Maria Amélia Dantes apud Maria Margaret Lopes (1997, p. 156-157). 
86. Ver Maria Margaret Lopes (1997).

87. Ver A Provincia de $S$. Paulo (08 jul. 1884, p. 1).

88. Ver A Provincia de $S$. Paulo (29 ago. 1884, p. 2).

89. Ver Paula Findlen (1994).

90. Cf. Carl von Koseritz (1980 [1883], p. 266).

91. Cf. Maria Margaret Lopes (2001, p. 883).
Portanto, era essencial entender a população brasileira para se compreender o que era o Brasil, e quais seriam as melhores formas de intervir na sua realidade, o que seria feito por meio das ciências. É a partir daí que pesquisas antropológicas - na busca de crânios e esqueletos indígenas, por exemplo - surgiram no país, assim como expedições de caráter nacional. Era esta também uma forma de se integrar às ciências europeias ${ }^{86}$. Sertório, portanto, não estava sozinho nessa busca de integrar o seu museu a um contexto internacional, muito menos com relação a algumas de suas práticas. $\bigcirc$ coronel, ao procurar tornar seu museu cada vez mais completo, seguiu uma determinada forma de fazer ciência que se assemelhava à concebida na Europa durante os séculos XVI, XVII e XVIII. Trała-se, claramente, de uma comparação entre lugares e épocas diferentes, no entanto não deixam de ser espantosas as similaridades dessas práticas em dois contextos tão distintos. $\bigcirc$ fato de o Coronel Sertório ter realizado expedições em busca de novos espécimes - como a sua ida a São Vicente para explorar sambaquis ${ }^{87}$ ou a Conceição de Itanhaém e Peruíbe ${ }^{88}$ - é bastante significativo, pois a atividade de viajar a uma certa distância da sua residência para procurar determinado item para a coleção era algo muito praticado entre naturalistas europeus do século XVII. Segundo Findlen, a coleção era o produto de inúmeras viagens pela natureza, tanto que, no final do século $\mathrm{XVI}$, viajar tornou-se um ritual de passagem para o aspirante a naturalista ${ }^{89}$.

Era comum que essas viagens fossem empreendidas em grupos: o colecionador/naturalista poderia ser acompanhado de outro cientista e de um ilustrador, cuja tarefa era a de desenhar, ou melhor, registrar as espécies observadas na natureza. Na viagem a Conceição de Itanhaém e Peruíbe, Sertório teve a companhia do botânico Alberto Loefgren, com quem explorou os sambaquis da região a fim de estudar a flora e a fauna do litoral e para formar uma coleção desse gênero a ser exposta no Museu. É provável que Sertório tenha realizado essa busca por sambaquis seguindo a crítica feita por Koseritz quando visitou seu museu: "Nada há sobre o homem americano, nem crânios ou ossos dos sambaquis, nem tampouco ossos das cavernas" 90 . Com isso, percebe-se que Sertório tinha por objetivo deixar suas coleções mais completas aos olhos de visitantes instruídos. Não se pretende inferir que Sertório fosse um cientista stricto sensu, mas apenas apontar que adotou uma determinada prática bastante comum entre os colecionadores europeus da era moderna que mantinham gabinetes pessoais, fossem eles naturalistas ou não.

Mesmo assim, é preciso destacar que o espaço do campo, ao contrário do espaço do laboratório, pelo seu caráter "essencialmente público", favorecia o trânsito de "amadores, coletores, comerciantes, estrangeiros" entre "especialistas, turistas, habitantes dos locais de investigação", sendo um meio em que "as práticas cotidianas dependem intensamente das condições dos contextos específicos dos locais em que se desenvolvem. As regras de sociabilidade de tais práticas requerem considerável grau de improvisação no tratamento de exigências locais" 1 " 
Museu Sertório ainda manteve um naturalista viajante, J.P. da Motta Junior, que em excursão pela província coletava itens considerados de interesse para a coleção. Sertório ainda planejava organizar um gabinete físico e um laboratório químico para palestras públicas, junto com o Museu, e, mesmo que esses planos não tenham sido realizados, é importante destacar a intenção de criar outros espaços de estudo. Como explicou Findlen, o laboratório, como um local repleto de objetos e instrumentos cujo uso levava ao conhecimento, representava - conjuntamente com o museu, em meados do século XVII - um lugar privilegiado de conhecimento por meio da "experiência" da natureza ${ }^{92}$. A intenção de se ter um local para preleções populares, para além do caráter instrutivo do museu do século XIX, pode estar ligada à ideia de um museu como um lugar em que teoria e prática se encontravam por meio de demonstrações públicas de experiências científicas ${ }^{93}$. No Museu Sertório, - laboratório seria o espaço onde aconteceriam essas aulas ${ }^{94}$, ligando-o a uma continuidade da cultura experimental do século XVII, que, de fato, foi amplamente praticada na Europa do século XIX, em outros contextos e com outras configurações.

Para além do contato de Sertório com o cientista Alberto Loefgren, é possível que o colecionador tenha tomado conhecimento dessas práticas a partir das atividades do Museu Nacional, a principal referência no campo das ciências no Brasil durante esse período. Em 1876, quando Ladislau Neto assumiu a direção da instituição, houve uma mudança no regulamento do Museu Nacional, que se voltava a partir daí "ao estudo da História Natural, particularmente da do Brasil, e ao ensino das ciências físicas e naturais, sobretudo em suas aplicações à agricultura, indústria e artes"95. As peças coletadas deveriam ser classificadas "com base nos métodos mais aceitos nos grêmios científicos modernos e conservando-as acompanhadas de indicações explicativas ao alcance dos entendidos e do público" 196 . É provável que essa tenha sido a concepção científica que os críticos à organização do Museu Sertório tinham em mente.

Museu Nacional também reuniu um grupo de naturalistas viajantes profissionais que contribuiu para o aumento das coleções, assim como para seu estudo e classificação. À diferença do Museu Sertório, de iniciativa particular, o Museu Nacional, uma instituição pública e com ambições de representar todo o território brasileiro, investia em expedições para várias outras províncias nacionais, a fim de fazer um "levantamento das condições materiais disponíveis para seu aproveitamento comercial e industrial"97, ao passo que a maior parte das viagens empreendidas pelo coronel e J.P. da Motta Jr. se limitavam ao estado paulista. No Museu Nacional, também foram criados um laboratório químico e uma biblioteca lque chegaram a funcionar, ao contrário do Museu Sertóriol, a fim de auxiliar na identificação dos produtos coletados, que seguiam os critérios que guiavam outras coleções do mundo, baseados na raridade das peças ${ }^{98}$.
92. Ver Paula Findlen (1994, p. 198).

93. Nas academias de ciências europeias dos séculos XVII e XVIII, assim como nos gabinetes ou studii do mesmo período, era comum existir um espaço - seja um laboratório ou não - para realizar experiências tanto para outros cientistas quanto para visitantes leigos - claro que com objetivos distintos: o primeiro, para produção de conhecimento, ganhando autoridade intelectual ao se valer de experiências; o segundo, para a diversão através do maravilhoso. Ver Paula Findlen (1994).

94. Até o momento, não foram encontrados indícios de que o Museu Sertório tenha sido palco de qualquer tipo de aula pública ou demonstração científica.

95. Ver Maria Margaret Lopes (1997, p. 159).

96. Cf. ibidem.

97. Cf. idem (p. 140)

98. Ibidem 
99. Até o momento não foi encontrada nenhuma menção à existência de um catálogo da coleção do coronel, por isso é possível que nunca tenha sido elaborado.

100. Ver Paula Findlen (1994, p. 36-37). Além disso, o catálogo era um importante veículo de difusão e divulgação da coleção pelo meio impresso, com o intuito de atingir um público mais amplo.

101. Cf. idem (p. 398).

102. Arthur Macgregor (2001).
Museu Sertório e o Ashmolean Museum

Mesmo diante das semelhanças entre dois períodos distintos, não se pode deixar de comentar um aspecto importante dos colecionadores da Europa moderna: a presença de um catálogo da coleção, que se encontrou ausente no caso do Museu Sertório, algo que não era incomum nas práticas dos naturalistas que formavam coleções ${ }^{99}$. $\bigcirc$ catálogo, segundo Findlen, é o objeto mais importante produzido a partir de uma coleção. Ao contrário do inventário que registra o conteúdo do museu, listando os objetos de forma quantitativa e não analítica, o catálogo leva à interpretação do acervo. Surgido no final do século XVI, o catálogo apresentava de forma consciente a coleção, sendo repositório de várias histórias cruzadas que textualizavam e contextualizavam cada objeto ${ }^{100}$. Com o catálogo, é possível ter uma noção da organização de uma coleção; na sua ausência, essa sistematização tende a permanecer desconhecida, sendo esse o caso do museu de Joaquim Sertório.

Mesmo assim, é interessante refletir que "a organização de uma coleção fornecia um método importante para distinguir os estudiosos da natureza de diletantes científicos"101. Ao adotar o princípio "moderno" de padronização de separação científica, baseada na divisão de disciplinas, o que se refletia no próprio espaço compartimentado do museu, os colecionadores do século XVIII procuravam evitar as "falsas conexões" feitas pelos naturalistas de períodos anteriores, que colocavam todos os artefatos juntos. Por esse viés, é difícil não colocar Sertório na categoria de "diletante científico".

Diante dessa trajetória é possível traçar um paralelo entre o Museu Sertório e o Ashmolean Museum of Art and Archaelogy, da Universidade de Oxford, Inglaterra, considerado um dos museus mais antigos do mundo, inaugurado em maio de 1683, ou, antes, inserir o Museu Paulista numa trajetória que tem como marco de referência o Ashmolean Museum, uma vez que este representa a passagem do gabinete de curiosidades para o museu moderno.

$\bigcirc$ Ashmolean Museum tem origem em uma coleção particular de objetos coletados por jardineiros reais, os Tradescants, John, o Velho, e John, o Moço, que foram acumulados na primeira metade do século XVII, constituindo-se como um exemplo de gabinete de curiosidades, já tendendo a uma configuração de museu moderno ${ }^{102}$. Em 1628, Tradescant e sua família se mudaram para uma casa em Lambeth, um distrito de Londres, onde desenvolveu a coleção; essa propriedade se tornaria conhecida posteriormente por The Ark, ou "A arca", em tradução livre. Essa expressão remete à ideia de um gabinete de curiosidades identificado com a bíblica Arca de Noé, em que Noé reuniu aos pares todos os espécimes de animais do mundo em uma embarcação a fim de sobreviver ao Grande Dilúvio enviado por Deus para extinguir os pecadores da terra; as espécies salvas deveriam repovoar o mundo novo purificado pelas águas divinas. A metáfora entre o gabinete de curiosidades e a Arca de Noé faz referência à ideia corrente de que o gabinete reunia todas as coisas do mundo em um só espaço. É interessante notar que essa mesma analogia foi feita pelo jornalista Ezequiel Freire com relação ao Museu Sertório: 
A praga iminente sobre a Província não é só de gafanhotos ou de rãs, mas de animais de toda espécie - verdadeira Arca de Noé que ameaça encalhar sobre o Ararał paulista. Refiro-me às variadíssimas coleções, propriedade do Sr. Coronel Sertório ${ }^{103}$.

Freire valeu-se da mesma analogia para criticar a falta de zelo por parte do governo com relação ao Museu Provincial ${ }^{104}$.

Pobres bichos! Inofensivos e empalhados! Quando, no dia do Juízo Final, ressurgirem os mortos, urrai, zurrai, assoviai contra os administradores que vos deram tão vagabunda vida! E, se houver novo dilúvio, metei-vos logo na Arca de Noé, fechando-the as portas, a ver se, no futuro repovoamento do mundo, acaba-se a espécie-presidente! 105

Mesmo assim, é necessário fazer uma ressalva teórica sobre os gabinetes de curiosidades - na visão de Schapper, "o gabinete de curiosidades é menos um teatro do mundo, ou uma arca de Noé generalizada, e mais uma representação do mundo pelas suas singularidades" 106 .

Voltando ao Ashmolean Museum, com a morte de Tradescant o Velho, em 1638, a coleção passou para as mãos do seu filho, que também a ampliou devido às suas viagens pelo mundo - seu pai também acumulou espécimes coletados em viagens. A coleção era aberta à visitação tanto de britânicos e estrangeiros ilustrados quanto de pessoas comuns, sendo sua acessibilidade um fator que distinguia os Tradescants da maioria dos colecionadores até então conhecidos na Inglaterra. Essa mesma política foi seguida pela Universidade de Oxford com o Ashmolean Museum que, ao contrário dos demais museus europeus, possibilitava a entrada de todo o tipo de público, criando uma

nova forma de instituição pública, aberta às pessoas que eram excluídas do mundo da educação, sendo essa a fronteira definida pela comunidade intelectual e que implicitamente determinava os princípios de entrada nos museus renascentistas e barrocos. Era um local claramente incivilizado ${ }^{107}$.

preço barato para entrar no estabelecimento alterava os padrões de gênero e classe social que definiam, até então, a natureza privada e exclusiva do museu. Segundo Richard Altick, o baixo custo de uma visita mercantilizava a experiência do estudo vinculada a esse tipo de espaço, altamente elitizado nos séculos XV e XV|108. Era o embate entre a visão mercantilista da sociedade em detrimento de uma visão de cultura cavalheiresca ${ }^{109}$, mas também uma nova concepção de instrução: a difusão do saber apareceu nessa época como uma responsabilidade pública; os soberanos acreditavam que, a partir daí, a comunicação do conhecimento era uma condição para o progresso ${ }^{110}$.

Museu Sertório não enfrentou exatamente esse tipo de confronto tão abertamente, uma vez que estava inserido em outro contexto, no Brasil do século XIX, que tinha a ideia - ao menos no plano discursivo - de que o progresso da nação estava vinculado à educação do seu povo. Ele foi aberto ao público em geral, já que passou a se mostrar como um instrumento importante no projeto
103. Cf. Correio Paulistano (27 set. 1882 , p. 2 ).

104. O Museu Provincial foi inaugurado em 1877 pela Associação Auxiliadora do Progresso da Província de S. Paulo. Era uma associação entre o poder público e os membros particulares da Associação. O governo providenciou o espaço para as coleções - no caso, uma das salas do edifício do Tesouro Provincial -, e ainda ficaria responsável pela manutenção das peças e a visitação ao público. As peças do Museu pertenciam a particulares, não apenas membros da Associação (inclusive, consta-se que o Coronel Sertório tenha sido um desses doadores). Ele chegou a ficar aberto ao público, no entanto, rapidamente entrou em declínio. Posteriormente, essas coleções foram incorporadas ao Museu Sertório.

105. Cf. Correio Paulistano (27 set. 1882 , p. 2 ).

106. Cf. Antoine Schnapper (1988, p. 175).

107. Cf. Paula Findlen (1994, p. 147).

108. Esse processo de mercantilização das coleções atingiu seu auge, na Inglaterra, no século XIX, quando os gabinetes dos estudiosos se tornaram "públicos", no sentido de não mais serem exclusivos para uma determinada classe intelectual. Ver Richard Altick (1978, p. 32).

109. Ver Paula Findlen, 1994.

110. Ver Roland Schaer (1993). 
111. Ana Maria de Alencar Alves, citando uma passagem do Primeiro Relatório do Museu do Estado, datado de outubro de 1891 e redigido pelo naturalista dinamarquês Alexander Hummel, ajudante interino do Museu do Estado, lançou pistas sobre que tipo de público frequentava o Museu Sertório: "A instrução portanto estava entre as finalidades pretendidas para o Museu do Estado. Mas a quem seria dirigida essa instrução? Hummel fornecia pistas, propondo uma mudança do tipo de público que frequentava o Museu, ao criticar o fato de ser, até então, visitado apenas por um pequeno número de privilegiados. Era preciso franquear os tesouros do Museu para a instrução popular e para um público mais amplo". Cf. Ana Maria de Alencar Alves (2001, p. 61).

112. Cf. Paula Findlen (1994, p. 149).

113. Cf. Idem (p. 150).

114. Cf. Maria Margaret Lopes \& Silvia Fernanda de Mendonça Figueirôa (2003). educativo do período. Mesmo assim, é importante assinalar que não existem dados concretos sobre o tipo de visitantes que o Museu Sertório recebia quando passou a abrir ao público la que camada social pertenciam, inclusive se eram ou não escravos, se eram instruídos ou não, se havia regras restritivas de acesso, etc. ${ }^{1}{ }^{1}$ ), como essas pessoas reagiam ao que viam, se apreendiam alguma coisa ou não, ou até mesmo se havia alguma etiqueta de comportamento para a visitação.

Com relação à coleção inglesa, o italiano Lorenzo Magalotti, secretário da Accademia del Cimento, quando da sua viagem à Inglaterra em meados do século XVII, ao visitar o Museum Trandescantium, comentou: "para falar a verdade, não há nada lá que possa ser chamado de raro hoje em dia e que mereça que se cruze o rio para ir ver (...)"112. Ou seja, "o museu de Tradescant continha objetos, mas não continha conhecimento"113, pelo menos de acordo com a sensibilidade italiana do período. De alguma forma, o mesmo pensamento pode ser transferido parcialmente para o Museu Sertório, pois, apesar de demonstrar ter a intenção de produzir conhecimento - como a criação de um laboratório anexo ao Museu e a publicação dos resultados obtidos com as escavações de sambaquis -, é duvidosa a ideia de que o coronel tenha efetivamente realizado essas aspirações. No entanto, é necessário ressaltar novamente que a ciência do século XVII era diferente da do século XIX, mas, mesmo seguindo a cartilha científica do seu tempo, parece que Sertório não conseguiu sistematizar sua coleção de acordo com as classificações científicas da época. Não se está inferindo que Sertório não tivesse uma organização para sua coleção, mas sim que ela não seguiu a sistematização científica então preconizada, ante os vários relatos que chamaram a atenção para essa caraterística do Museu, e a organização de caráter científico era característica importante para se estudar tendo por base um museu.

Diante dessa questão, não se pode deixar de reproduzir a opinião do cientista Orville Derby, presidente da Comissão Geográfica e Geológica, a que estava subordinado o Museu do Estado, sobre as coleções doadas ao governo pelo Conselheiro Mayrink, enunciada em correspondência ao futuro diretor do Museu Paulista, o zoólogo Hermann von Ihering:

Quanto ao Museu está muito melhor atualmente e está temporariamente abrigado numa casa particular. É uma coleção de curiosidades que foi presenteada ao Estado e que tem pequeno valor científico, exceto como um alicerce para se construir alguma coisa no futuro. Ele é tão insignificante, entretanto, que meus planos eram fazer de você o chefe da Seção de Zoologia, encarregado do Museu, que só depois pode conseguir importância suficiente para ser independente.

(...) em primeiro lugar, o governo de São Paulo não está especialmente interessado nem em estudos zoológicos nem no museu, considerando este último mais bem como uma espécie de elefante branco (...) uma opinião com a qual eu intimamente concordo. Ele consiste de uma coleção privada feita por um 'curioso' e vendida por ele junto com a casa para um rico especulador durante o 'boom' [do café], o qual fez presente da coleção ao governo e ficou com a casa. $\bigcirc$ governo, não sabendo o que fazer com ela e não desejando incorrer em despesa, 'encostou' o museu na Comissão, e eu muito relutantemente aceitei o encargo a fim de preservar o que havia de valor nas coleções e para manter viva a ideia de um museu, que no futuro poderá se transformar em algo melhor ${ }^{114}$. 
Na visão de Derby, portanto, a coleção Sertório doada ao governo não possuía valor científico algum, a não ser como ponto de partida para a criação de um museu na cidade. Ao mesmo tempo, o Museu Sertório estava inserido no projeto de instrução de São Paulo, baseado no método intuitivo e na "pedagogia do olhar", que tinha por intuito educar pela visão por meio da exposição de objetos.

Retomando a aproximação com o Ashmolean Museum, observa-se que a coleção Tradescant só passou a ser reconhecida pelo seu caráter científico quando foi assumida por Elias Ashmole, homem de posição social respeitável, sendo um dos membros fundadores da Royal Society - sociedade científica de Londres. Ashmole, que também era colecionador, doou a coleção para a Universidade de Oxford - onde estudou por um breve período -; o museu a ser organizado levaria o seu nome: Ashmolean Museum, tornando-se o principal foco do investimento científico da instituição. O Museu Sertório, ao contrário, foi comprado pelo Conselheiro Mayrink, mas este também doou a coleção, não para uma universidade (que não havia em São Paulo na época), mas para o Governo de São Paulo, com o intuito de se constituir um museu na capital com caráter de instituição científica; o Museu Paulista passaria a ter caráter universitário mais tarde.

No caso do Ashmolean Museum, não foi a mera aquisição dessa coleção que incentivou esse processo, uma vez que a própria biblioteca da universidade, a Bodleian Library, possuía um gabinete de curiosidades. 0 diferencial para o sucesso do Ashmolean Museum, segundo Macgregor, recaía sobre o seu laboratório e auditório para aulas, que ocupavam o subterrâneo e o andar térreo do prédio em que se encontrava, atraindo maior interesse científico que o próprio museu, que se localizava no primeiro andar ${ }^{15}$. De acordo com Roland Schaer, a vice-chancelaria da Universidade de Oxford via o museu como uma nova biblioteca ${ }^{116}$. Para Schaer, o museu é a forma organizada da experiência sensível, que passou a ser consagrada como uma fonte essencial de conhecimento e instrução. Por isso a presença de uma escola e de um laboratório em seu entorno. Ainda segundo esse autor, a associação entre biblioteca e museu representava, portanto, as duas principais fontes de saber: as palavras e as coisas. Com o passar dos anos, a natureza e a organização das coleções romperam com a tradição da curiosidade, com o advento de uma grande especialização e, ao mesmo tempo, não se contentando apenas com raridades. A ideia era formar um "inventário da natureza", que incluiria não apenas as coisas estranhas e raras, mas também as mais conhecidas e comuns. $\bigcirc$ estudo da natureza passou pela reconstituição da grande cadeia dos seres vivos para a comparação e classificação de espécies. As coleções foram, assim, usadas como suporte de "demonstração" para estudo e difusão. $\bigcirc$ museu tornou-se, com isso, um espaço para demonstrações 117 , de "ver para aprender". A ideia de constituir um gabinete físico e um laboratório químico para sediar palestras públicas para o acesso geral foi acalentada por Sertório, mas, aparentemente, nunca realizada.
115. Cf. Arthur Macgregor (1985).

116. Ver Roland Schaer (1993, p. 33).

117. Ibidem. 
118. Cf. Correio Paulistano (27 set. 1882, p. 2).

119. Cf. idem (p. 2).

120. Cf. Carl von Koseritz (1980 [1883], p. 265-266).

121. Cf. Henrique Raffard (1977 [1890], p. 87). O autor ainda comentou que Laurindo preparou "pouco a pouco" algumas aves obtidas no Jardim Público de São Paulo. Um "Laurindo Sertório" foi mencionado n'A Provincia de S. Paulo (12 abr. 1891. p. 2): "Os cidadãos G. Friedenreich e A. Hummel foram nomeados ajudantes e Laurindo Sertório servente do museu desta capital. Os primeiros terão o vencimento de $150 \$ 000$ mensais e o último 60\$000”. Provavelmente, Laurindo foi um escravo de Sertório que permaneceu trabalhando para o coronel após a Abolição da Escravidão, em 1888, e com a doação do Museu para o Governo do Estado, foi chamado a ser o primeiro servente da instituição.

122. Ver Carlos Eugênio Marcondes de Moura (1998, p. 238). Não deixa de ser notável que a Família Imperial brasileira tenha visitado o Museu Sertório em algumas ocasiões, quando em São Paulo. O mesmo acontecia com os colecionadores da Itália renascentista estudados por Paula Findlen, que observou: "Possuir um museu era uma forma de subir na escala social. Curiosidade não era apenas um agente de elevação social, mas também mitigava as diferenças de nascimento e linhagem, oferecendo um ponto de cruzamento entre grupos socialmente diferenciados". Cf. Paula Findlen (1994, p. 41-42).

123. Ver A Provincia de $S$. Paulo (26 set. 1884, p. 2).

124. Era prática comum os museus e gabinetes europeus
Museu Sertório e a educação

Com relação à visitação, o Museu Sertório, a princípio, estava aberto aos "simples curiosos e homens da ciência"118, como descreveu Ezequiel Freire, uma vez que "o amável proprietário dessas riquezas concedia-lhes franca visita às mesmas"119. O Coronel Sertório tinha por hábito, inclusive, guiar os visitantes por seu acervo. Koseritz relatou que o "coronel se alegra muito quando pode mostrar suas coleções" 120 . Já Raffard lamentou a ausência do proprietário no momento da sua visita, tendo sido ciceroneado "pelo cidadão Laurindo, descendente de africano"121. A mesma observação foi externada pela Princesa Isabel, em seu diário ${ }^{122}$.

A ideia de abrir o Museu ao público apareceu pela primeira vez na imprensa em 1884 ${ }^{123}$. Em 1886, uma notícia indicou que o Museu vinha sendo aberto ao público aos domingos, com grande sucesso, e que o local possuía até mesmo um álbum de visitantes ${ }^{124}$, tendo sido visitado "nos últimos dois domingos" por 364 pessoas $^{125}$.

No ano seguinte, anunciou-se que "este importante museu pode ser visitado hoje pelo público, se não chover, das 10 horas da manhã às 3 da tarde"126. Com a inauguração em um novo endereço para abrigar suas coleções e a grande frequência de visitantes, Sertório encarregou um administrador, José Augusto Quirino dos Santos, para receber o público, que deveria pagar para poder ver as coleções ${ }^{127}$. O Museu passou a ser aberto às quintas e aos domingos; uma entrada de mil réis era cobrada dos adultos, ao passo que as crianças não pagavam ${ }^{128}$. Meses depois, o Museu começou a ser aberto todos os dias ${ }^{129}$. É interessante perceber como o Museu Sertório entrou para o imaginário da cidade no final do século XIX, sendo até inserido em críticas ácidas de teor político:

CÂMARA... ARDENTE (...) Dado porém o caso de haver um símile entre as duas câmaras [câmara mortuária e câmara dos deputados], quem representaria o papel do morto no recinto do ex-congresso? Ninguém, está bem visto.

Agora, se houvesse mesmo muita necessidade de um morto, bastar-the-ia pedir ao Museu Sertório um macaco empalhado, parecido algum tanto com o Sr. Lucena ${ }^{130}$.

\section{E em anedotas macabras:}

Um poeta (sempre os poetas!), que abandonou já os bancos acadêmicos, trazendo para a vida prática um canudo e um livro de versos, um dia cantou Eureka, batendo com a testa na parede de seu gabinete de estudo, como se o encéfalo houvesse dado à luz uma ideia fosforescente, uma ideia digna de ser empalhada e figurada no Museu Sertório ${ }^{131}$.

Esses textos impressos no jornal mostram a importância do Museu Sertório para São Paulo, tanto por dar acesso ao público em geral quanto pela sua identificação com a própria cidade, tornando-se uma espécie de patrimônio local, embora fosse de caráter particular. A visitação do público estava intrinsecamente ligada ao papel que se atribuía ao Museu na educação da 
população, como se depreende no informe enviado por Sertório aos jornais em 1884, em que pedia auxílio para completar as suas coleções, "cujo fim especial é a instrução, oferecendo à vista de todos as nossas riquezas naturais"132.

Quando resolveu abrir diariamente seu Museu, o coronel informou que a entrada era gratuita às autoridades públicas, aos diretores de colégio acompanhados de seus alunos e aos representantes da imprensa ${ }^{133}$. $\bigcirc$ jornal $\bigcirc$ Estado de S. Paulo avisou que o professor Lamartine Delamare, diretor do Collegio Delamare - "acreditado estabelecimento de ensino da capital" - realizou uma visita com seus alunos ao Museu Sertório, onde aproveitou o "ensejo para fazer-thes uma preleção sobre alguns espécimes mineralógicos"134. Essas notícias demonstram o caráter instrutivo do Museu Sertório que, por sua vez recebia - e incentivava visitas escolares.

É interessante ressaltar que o Museu Provincial, aberto em 1877, já possuía esse caráter instrutivo, uma vez que chegou a receber visitas de professores, acompanhados de seus alunos, vindos de outros estados ${ }^{135}$. Documentos de 1871 , que assinalavam para a criação de um Museu Paulista, justificavam essa medida com fins de se forjar um "estabelecimento tão necessário à instrução do povo e aos interesses da indústria", nas palavras do engenheiro da Comissão Geológica e Geográfica da época, J. Cantinho ${ }^{136}$.

Segundo Barbuy, o museu que surgiu na Europa no século XIX, e que tem suas versões brasileiras, já nasceu didático, com fins de instruir o povo a partir da visualidade ${ }^{137}$. Nesse contexto, segundo Lopes, os museus gestaram "novas formas de sociabilidade", que deslocaram os novos entendimentos da natureza de "exclusivamente textual para o tátil, para o visual, para o colecionável", convertendose "em verdadeiras escolas abertas, onde tanto o público leigo podia adquirir e exibir maneiras civilizadas e se educar, como o naturalista podia realizar seus estudos taxonômicos pelo simples olhar comparativo"138.

Vidal observou que o papel dos museus se modificou em sintonia com os novos parâmetros de conhecimento científico, que identificavam a natureza como local de respostas para os mistérios da realidade e do homem com um novo método: de uma pedagogia "do ouvir" deslocava-se para a "do olhar", no fim do século XIX, ao mesmo tempo que a arte de memorizar perdia seu prestígio ${ }^{139}$. De acordo com Maria Cecília Souza, no Brasil da segunda metade do século XIX, a desqualificação da memória foi uma condenação a um modelo de ensino associado às práticas religiosas e ao passado escravista, apoiando-se em habilidades mecânicas vistas como inferiores e capazes de fazer as camadas populares chegarem à civilização e ao poder, ocultando-lhes, porém não corrigindo, os efeitos do determinismo racial ${ }^{140}$. Portanto, o método intuitivo foi considerado "peça central nas estratégias republicanas de constituição de um sistema de educação pública em São Paulo"141

A educação de fins do século XIX - pelo menos em São Paulo e Rio de Janeiro - estava, portanto, calcada nos princípios do ensino pela experiência concreta ou pela observação. Com isso, percebe-se o poder didático atribuído à da era moderna possuírem um livro de visitantes, com nomes de homens ilustres, com o intuito de "imortalizar a fama de um museu e de seu criador ao registrar a conexão com os centros de poder sociais, políticos e intelectuais". Cf. Paula Findlen (1994, p. 137). Ainda são desconhecidos os nomes que figuravam no álbum de visitantes do Museu Sertório, uma vez que ele não foi localizado e provavelmente não exista mais.

125. Cf. Correio Paulistano (14 dez. 1886, p. 3).

126. Cf. A Provincia de $S$. Paulo (09 jan. 1887, p. 2)

127. Ver O Estado de S. Paulo (15 fev. 1890, p. 1).

128. Ver O Estado de S. Paulo (17 fev. 1890, p. 3).

129. Ver O Estado de S. Paulo (29 abr. 1890, p. 1).

130. Cf. Correio Paulistano (22 jul. 1891, p. 1).

131. Cf. Correio Paulistano (24 fev. 1888, p. 2). O museu de história natural funcionou, inclusive, como uma referência cultural do período, sendo também incorporado a anedotas publicadas no jornal, mostrando o viés do "bizarro" desse tipo de instituição: "Entre dois vadios: / - O que faz teu pai? / - Pede esmolas / - E tua mãe? / - É mendiga. / - E teu irmão? / - Meu irmão... está no Museu de história natural. / - E que faz ele no Museu? / - Está dentro de um vidro cheio de álcool, porque veio ao mundo com duas cabeças." Correio Paulistano (10 fev. 1894, p. 2).

132. Cf. Correio Paulistano (27 set. 1884 , p. 1).

133. Ver O Estado de S. Paulo (29 abr. 1890).

134. Cf. O Estado de S. Paulo (12 jun. 1890, p. 1). 
135. Ver A Provincia de $S$. Paulo (19 jan. 1881, p. 2).

136. Cf. Arquivo do Estado de S. Paulo: Ofício de João Martins da Silva Cantinho ao Vice-Presidente da Província (24 maio 1871); Ofício de João Martins da Silva Cantinho ao Dr. José Fernandes da Costa Pereira (1 ${ }^{\circ}$ jun. 1871).

137. Ver Heloisa Barbuy (2002, p. 67).

138. Cf. Maria Margaret Lopes (2001, p. 883).

139. Cf. Diana Gonçalves Vidal e Maria Cecilia Souza (1999, p. 111).

140. Ver Diana Gonçalves Vidal e Maria Cecilia Souza (1999). "O tema racial, apesar de suas implicações negativas, se transforma em um novo argumento de sucesso para o estabelecimento das diferenças sociais. Mas a adoção dessas teorias não podia ser tão imediata nesse contexto. De um lado, esses modelos pareciam justificar cientificamente organizações e hierarquias tradicionais que pela primeira vez - com o final da escravidão começavam a ser publicamente colocadas em questão. De outro lado, porém, devido à sua interpretação pessimista da mestiçagem, tais teorias acabavam por inviabilizar um projeto nacional que mal começara a se montar". Cf. Lilia Moritz Schwarcz (2007, p. 18).

141. Marta Carvalho apud Diana Gonçalves Vidal (1999, p. 112).

142. Cf. Heloisa Barbuy (2002, p. 74).

143. Ver Correio Paulistano (27 set. 1882). Quando da inauguração do Museu Provincial, em 1877, a imprensa vinculava diretamente a inauguração de um museu com o desenvolvimento da ciência visão, baseado na ideia de "ver para compreender", buscando ver o todo em diversas formas de exposição, "como 'palavras de acesso' para a inteligibilidade do mundo" 142. Os museus passaram, então, a fazer parte essencial da educação do povo ao complementar o ensino escolar, e a visão tornou-se o sentido mais valorizado para o aprendizado. A presença de um museu em uma cidade também estava ligada à ideia de progresso e civilização ${ }^{143}$. O pensamento da época associava a presença de um museu como valioso para o conhecimento da cultura nacional ou local que, aliado ao estudo das ciências, levaria ao progresso intelectual e moral.

São Paulo passava por um período de desenvolvimento acelerado, iniciado na segunda metade do século XIX, devido principalmente aos ganhos advindos da exportação do café, o que levou a uma incipiente industrialização e a uma crescente expansão urbana ${ }^{144}$. A presença de centros de instrução, incluindose os museus, na ideologia do fim do século XIX, era um sinal de "progresso", já que a educação era tida como fundamental para o avanço do Estado, no que incluía mudanças no ensino, que deveria adotar o método intuitivo. Uma parte (ainda que reduzida) da sociedade paulista via no museu de História Natural um vínculo direto a uma questão de suma importância: a educação da população ${ }^{145}$, fundamentada em um ensino prático baseado na observação ${ }^{146}$.

A criação de um museu estava, pois, ligada a um projeto de parte da elite política e econômica paulista, que via na construção de um museu estadual uma forma de legitimação no cenário nacional - diante do poder exercido por essa elite nos começos do período republicano -, uma vez que um museu científico era importante elemento de modernização do estado ${ }^{147}$.

Para concluir, é importante pensar sobre o suposto diletantismo do Coronel Sertório a partir das suas práticas colecionistas, sendo que empreendeu uma série de atividades de cunho científico, o que se refletiu no caráter educativo que o Museu Sertório foi ganhando ao longo do tempo, além de sua associação simbólica com São Paulo. Nesse contexto, a criação de um museu em São Paulo estava ligada à ideologia modernizadora do progresso material, atrelada diretamente ao desenvolvimento científico - por meio da educação - que trabalharia em nome do desenvolvimento industrial do estado. Era também uma forma representativa de projetar essa imagem tanto no âmbito nacional quanto internacional, já que se pretendia inserir São Paulo como uma grande metrópole do mundo dito civilizado, vinculando-se, pois, à Europa. 


\section{REFERÊNCIAS}

ALTICK, Richard Daniel. The Shows of London. Londres: The Belknap Press, 1978.

ALVES, Ana Maria de Alencar. O Ipiranga apropriado: ciência, política e poder: o Museu Paulista, 1893-1922. São Paulo: Humanitas, FFLCH-USP, 2001 (Série Teses).

BARBUY, Heloisa. Museus, exposições e cidades: cultura visual no século XIX. In: OLIVEIRA, Cecilia Helena de Salles; BARBUY, Heloisa (Org.). Imagem e produção de conbecimento. São Paulo: Museu Paulista USP, 2002.

BURKE, Peter. Qualche riflessione sull'antropologia storica del collezionismo. In: AIKEMA, Bernard; LAUBER, Rosella; SEIDEL, Max (Org.). Il collezionismo a Venezia e nel Veneto ai tempi della Serenissima. Veneza: Marsilio, 2005. p. 51-54.

CARVAlHO, Paula Carolina de Andrade. O Museu Sertório: uma coleção particular em São Paulo no final do século XIX. Anais do Museu Paulista: História e Cultura Material, São Paulo, v. 22, n. 2, p. 105-152, 2014.

ELIAS, Maria José. Museu Paulista: memória e história. 1996. 2v. Tese (Doutorado em História) - Departamento de História da Faculdade de Filosofia, Letras e Ciências Humanas, Universidade de São Paulo, 1996.

FINDLEN, Paula. Possessing Nature: Museums, Collecting and Scientific Culture in Early Modern Italy. Berkeley: University of California, 1994.

KOSERITZ, Carl von. Imagens do Brasil. Belo Horizonte: Itatiaia; São Paulo: EDUSP, 1980. (Reconquista do Brasil. Nova série, v. 22). [1883].

LOMONACO, Alfonso. Al Brasile. Milão: Dott Leonardo Vallardi Edit, 1889.

LOPES, Maria Margaret. O Brasil descobre a pesquisa científica: os museus e as ciências naturais no século XIX. São Paulo: Hucitec, 1997.

. Viajando pelo campo e pelas coleções: aspectos de uma controvérsia paleontológica. História, Ciência, Saúde-Manguinbos, Rio de Janeiro, v. 8, p. 881-897, 2001.

LOPES, Maria Margaret; FIGUEIRÔA, Silvia Fernanda de Mendonça. A criação do Museu Paulista na correspondência de Hermann von Ihering: 1850-1930. Anais do Museu Paulista: História e Cultura Material, São Paulo, v. 10-11, n. 1, p. 23-35, 2003.

MACGREGOR, Arthur. The Ashmolean Museum: a Brief History of the Museum and its Collections. Oxford: Ashmolean Museum in association with Jonathan Horne, 2001.

MORAES, Fábio Rodrigo. Uma coleção de história em um museu de ciências naturais: o Museu Paulista de Hermann von Ihering. Anais do Museu Paulista: História e Cultura Material, São Paulo, v. 16, n. 1, p. 203-233, 2008.

MOURA, Carlos Eugênio Marcondes de (Org.). Vida cotidiana em São Paulo no século XIX: memórias, depoimentos, evocações. São Paulo: Ateliê Editorial; Imprensa Oficial; Ed. Unesp, 1998. e da educação (como também o desenvolvimento da indústria).

144. É importante destacar que o desenvolvimento de São Paulo não ocorreu somente a partir do café, uma vez que estudos recentes apontam para uma economia dinâmica já durante o período colonial, baseada não só na agricultura, mas no comércio.

145. Com relação à ideia de população, não se pode esquecer o contexto da derrocada da escravidão no Brasil, transformando - pelo menos na teoria - um contingente de escravos em cidadãos do país, sendo necessário, portanto, reforçar outros padrões de diferenciação, nesse caso, com base na ideia de raça. "Para além dos problemas mais prementes relativos à substituição da mão-de-obra ou mesmo à conservação de uma hierarquia social bastante rígida, parecia ser preciso estabelecer critérios diferenciados da cidadania". Cf. Lilia Moritz Schwarcz (2007, p. 18)

146. Ver Ana Maria de Alencar Alves (2001, p. 4951).

147. Ver Fábio Rodrigo Moraes (2008). 
OLMI, Giuseppe. Italian Cabinets of the Sixteenth and Seventeenth Centuries. In: IMPEY, Oliver; MACGREGOR, Arthur (Edit.). The Origins of Museums: the Cabinet of Curiosities in Sixteenth and Seventeenth-Century Europe. Oxford: Clarendon Press, 1985.

POMIAN, Krzysztof. Colecção. In: Enciclopédia Einaudi, Lisboa: Imprensa Nacional-Casa da Moeda, v. 1, p. 51-86, 1984.

RAFFARD, Henrique. Alguns dias na pauliceia. São Paulo: Academia Paulista de Letras, 1977. [1890].

SANJAD, Nelson. A coruja de Minerva: o Museu Paraense entre o Império e a República: 1866-1907. 2005. Tese (Doutorado em História das Ciências da Saúde) - Casa de Oswaldo Cruz, FIOCRUZ, Rio de Janeiro, 2005.

SCHAER, Roland. L'invention des musées. Paris: Gallimard / Réunion des Musées nationaux, 1993.

SCHNAPPER, Antoine. Le géant, la licorne at la tulipe: collections françaises au XVIIe siècle. Paris: Flammarion, 1988.

SCHWARCZ, Lilia Moritz. O espetáculo das raças: cientistas, instituições e questão racial no Brasil: 1870-1930. São Paulo: Companhia das Letras, 2007. [1993].

VIDAL, Diana Gonçalves; SOUZA, Maria Cecilia Cortez C. de. A memória e a sombra: a escola brasileira entre o Império e a República. Belo Horizonte: Autêntica, 1999.

Artigo apresentado em 30/06/2015. Aprovado em 13/08/2015. 